\title{
DAVID: Database for Annotation, Visualization, and Integrated Discovery
}

\author{
Glynn Dennis Jr*, Brad T Sherman*, Douglas A Hosack*, Jun Yang*, Wei \\ $\mathrm{GaO}^{*}, \mathrm{H}$ Clifford Lane ${ }^{\dagger}$ and Richard A Lempicki*
}

Addresses: *Science Applications International Corporation-Frederick, Clinical Services Program, Laboratory of Immunopathogenesis and Bioinformatics, National Cancer Institute at Frederick, MD 21702, USA. 'Laboratory of Immunoregulation, National Institute of Allergy and Infectious Diseases, National Institutes of Health, Bethesda, MD 20892, USA.

Correspondence: Glynn Dennis Jr. E-mail: GDennis@niaid.nih.gov

Posted: 3 April 2003

Received: 28 March 2003

Genome Biology 2003, 4:P3

The electronic version of this article is the complete one and can be found online at http://genomebiology.com/2003/4/5/P3

This is the first version of this article to be made available publicly. A peer-reviewed and modified version is now available in full at

(c) 2003 BioMed Central Ltd http://genomebiology.com/2003/4/9/R60

AS A SERVICE TO THE RESEARCH COMMUNITY, GENOME BIOLOGY PROVIDES A 'PREPRINT' DEPOSITORY TO WHICH ANY ORIGINAL RESEARCH CAN BE SUBMITTED AND WHICH ALL INDIVIDUALS CAN ACCESS FREE OF CHARGE. ANY ARTICLE CAN BE SUBMITTED BY AUTHORS, WHO HAVE SOLE RESPONSIBILITY FOR

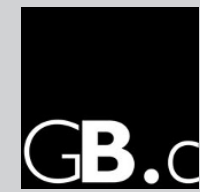
THE ARTICLE'S CONTENT. THE ONLY SCREENING IS TO ENSURE RELEVANCE OF THE PREPRINT TO GENOME BIOLOGY'S SCOPE AND TO AVOID ABUSIVE, LIBELLOUS OR INDECENT ARTICLES. ARTICLES IN THIS SECTION OF THE JOURNAL HAVE NOT BEEN PEER-REVIEWED. EACH PREPRINT HAS A PERMANENT URL, BY WHICH IT CAN BE CITED. RESEARCH SUBMITTED TO THE PREPRINT DEPOSITORY MAY BE SIMULTANEOUSLY OR SUBSEQUENTLY SUBMITTED TO GENOME BIOLOGY OR ANY OTHER PUBLICATION FOR PEER REVIEW; THE ONLY REQUIREMENT IS AN EXPLICIT CITATION OF, AND LINK TO, THE PREPRINT IN ANY VERSION OF THE ARTICLE THAT IS EVENTUALLY PUBLISHED. IF POSSIBLE, GENOME BIOLOGY WILL PROVIDE A RECIPROCAL LINK FROM THE PREPRINT TO THE PUBLISHED ARTICLE. 